\title{
Single residue modifications of the delta opioid receptor selective peptide, [D-Pen ${ }^{2}, \mathrm{D}-\mathrm{Pen}^{5}$ ]-enkephalin (DPDPE)
}

\author{
Correlation of pharmacological effects with structural and conformational features
}

\author{
RONALD C. HAASETH, KATARZYNA SOBCZYK-KOJIRO, FEDOR MEDZIHRADSKY ${ }^{1.2}$, CHARLES B. SMITH $^{2}$ and \\ HENRY I. MOSBERG \\ College of Pharmacy, 'Department of Biological Chemistry, and ${ }^{2}$ Department of Pharmacology, University of Michigan, \\ Ann Arbor, Michigan, USA
}

Received 27 October 1989, accepted for publication 28 January 1990

\begin{abstract}
Six analogs of the highly delta opioid receptor selective, conformationally restricted, cyclic peptide [DPen $^{2}, \mathrm{D}-\mathrm{Pen}^{5}$ ]enkephalin, Tyr-D-Pen-Gly-Phe-D-PenOH (DPDPE), were synthesized and evaluated for opioid activity in rat brain receptor binding and mouse vas deferens (MVD) smooth muscle assays. All analogs were single amino acid modifications of DPDPE and employed amino acid substitutions of known effects in linear enkephalin analogs. The effect on binding affinity and MVD potency of each modification within the DPDPE structural framework was consistent with the previous reports on similarly substituted linear analogs. Conformational features of four of the modified DPDPE analogs were examined by ${ }^{1} \mathbf{H}$ NMR spectroscopy and compared with DPDPE. From these studies it was concluded that the observed pharmacological differences with DPDPE displayed by diallyltyrosine ${ }^{1}$-DPDPE ([DAT ${ }^{1}$ ]DPDPE) and phenylglycine $e^{4}$-DPDPE ([Pgl $\left.{ }^{4}\right]$ DPDPE) are due to structural and/or conformational differences localized near the substituted amino acid. The observed enhanced $\mu$ receptor binding affinity of the carboxamide terminal DPDPE- $\mathrm{NH}_{2}$ appears to be founded solely upon electronic differences, the NMR data suggesting indistinguishable conformations. The observation that the $\alpha$-aminoisobutyric acid substituted analog [Aib ${ }^{3}$ DPDPE displays similar in vitro opioid behavior as DPDPE while apparently assuming a significantly different solution conformation suggests that further detailed conformational analysis of this analog will aid the elucidation of the key structural and conformational features required for action at the $\delta$ opioid receptor.
\end{abstract}

Key words: conformation-activity; conformational restrictions; enkephalins; 'H-NMR; structure-activity

[D-Pen ${ }^{2}$, D-Pen ${ }^{5}$ ]enkephalin (Tyr-D-Pen-G]y-Phe-DPenOH, DPDPE), a cyclic, disulfide containing analog of the endogenous opioid peptides, Leu- and Met-enkephalin, has been shown to be a highly selective ligand for the $\delta$ type of opioid receptor (1). Unlike the endogenous, linear enkephalins, DPDPE is relatively inflexible as a result of the conformational restrictions imposed by cyclization via a disulfide bond

Abbreviations recommended by IUPAC-IUB Commission of Biochemical Nomenclature have been used. Other abbreviations: Pen, penicillamine; DPDPE, [D-Pen ${ }^{2}, \mathrm{D}-\mathrm{Pen}^{5}$ ]enkephalin; Aib, $\alpha$-aminoisobutyric acid; ${ }^{1} \mathrm{H}-\mathrm{NMR}$, proton nuclear magnetic resonance spectroscopy; DMF, $N, N$-dimethylformamide; HPLC, high performance liquid chromatography; TFA, trifluoroacetic acid; MVD, mouse vas deferens; DAT, $N, N$-diallyltyrosine; Sar, sarcosine; Pgl, phenylglycine; DMSO, dimethylsulfoxide. and due to the further rigidizing effect of the penicillamine gem-dimethyl groups within the ring. This rigidity limits the number of conformations possible for the ligand to adopt in solution as well as at the receptor and renders the conformation of DPDPE less likely to be influenced by environment. Thus, conformational analysis of DPDPE in solution should allow inferences regarding the active, receptor bound conformation to be drawn. Nonetheless, despite the considerable efforts of several research groups (2-8), no consensus has been reached regarding the solution or receptor bound conformation of DPDPE. The further goal of elucidating the key structural and conformational elements underlying the delta receptor affinity and selectivity of DPDPE thus requires a different approach. One such approach is to use DPDPE as a 


\section{R.C. Haaseth et al.}

template for further modifications in a series of structurally related analogs for which correlation of the structural and conformational features with the observed potency and receptor selectivities, by revealing those features consistent and inconsistent with delta receptor affinity and selectivity, can be used to develop a topographic map of the delta opioid receptor binding site. Such studies can also provide insight into those features necessary for interaction with other opioid receptor types. For example, we have described one such study involving the differences in the $\mu$ and $\delta$ receptor topographies as evidenced in a series of DPDPE analogs in which the residue 2 side chain was varied (9). It was shown that the selectivity of DPDPE for the $\delta$ receptor over the $\mu$ receptor is due largely to steric hinderance to binding at the $\mu$ receptor attributable to the $\mathrm{D}-\mathrm{Pen}^{2}$ pro- $R \boldsymbol{\beta}$-methyl group.

We report here the synthesis, opioid receptor binding affinities and mouse vas deferens potencies of several analogs in which modifications of known pharmacological effect in linear enkephalin analogs have been incorporated within the more conformationally restricted framework of DPDPE. Within this series, modifications of residue 1 ( $N, N$-diallyltyrosine, DAT), residue 3 (sarcosine, Sar and $\alpha$-aminoisobutyric acid, Aib), residue 4 (D-Phe and phenylglycine, $\mathrm{Pgl}$ ), and residue 5 (carboxamide terminal, D-Pen$\mathrm{NH}_{2}$ ) were evaluated. In general the effects of these modifications within the DPDPE template mirror those observed in similarly modified linear enkephalin analogs. Initial conformation analysis via ${ }^{1} \mathrm{H}$ NMR spectroscopy was performed on several of the modified DPDPE analogs allowing differences in pharmacological action arising from structural versus conformational changes to be distinguished. Particularly noteworthy among the findings are the high delta receptor affinity, potency, and selectivity displayed by one of these analogs, $\left[\mathrm{Aib}^{3}\right] \mathrm{DPDPE}$, which appears to be conformationally different from DPDPE. This analog promises to be useful for distinguishing the most likely among the proposed conformational models for DPDPE and for the elucidation of the key structural elements and their conformational arrangement which comprise the $\delta$ opioid receptor pharmacophore.

\section{MATERIALS AND METHODS}

\section{Syntheses}

Unless otherwise noted, the peptides newly reported here were synthesized in a sequential fashion by solid phase methods as described earlier for the parent [D-Pen ${ }^{2}$, D-Pen $\left.{ }^{5}\right]$ enkephalin (1). Synthesis of carboxylic acid terminal peptides utilized chloromethylated polystyrene (Merrifield) resin, crosslinked with $1 \%$ divinylbenzene, while synthesis of the carboxamide terminal analog, DPDPE- $\mathrm{NH}_{2}$, employed $p$-methyl benzhydrylamine resin. $t$-Butyloxycarbonyl (Boc) protection of the $\alpha$-amino function was used throughout. The labile sulfur-containing side chain of the Pen residues was protected with the $p$-methylbenzyl ( $p$ MeBzl) function. For all peptides, cleavage of the peptide-resin was accomplished by treating $1.0 \mathrm{~g}$ peptide-resin with $10 \mathrm{~mL}$ anhydrous $\mathrm{HF}$ in the presence of $0.5 \mathrm{~g}$ thiocresol and $0.5 \mathrm{~g}$ cresol. After stirring for $1 \mathrm{~h}$ at $0^{\circ}$, the solvent was removed under vacuum and the resin was washed several times with dry ether. The peptide was extracted from the resin with $3 \times 5 \mathrm{~mL}$ washes of DMF $/ 80 \%$ acetic acid (9/1), diluted to $400 \mathrm{~mL}$ with $25 \%$ acetic acid solution, and lyophilized. Purification of the resulting free sulfhydrylcontaining, linear peptides was effected by semipreparative HPLC on a Vydac 218TP C-18 column $(2.2 \mathrm{~cm} \times 25 \mathrm{~cm})$ with the solvent system $0.1 \%$ TFA in $\mathrm{H}_{2} \mathrm{O} / 0.1 \%$ TFA in $\mathrm{CH}_{3} \mathrm{CN}$, using a $0-50 \%$ gradient of organic component. Cyclization to the desired disulfide-containing analogs was effected by treatment with $\mathrm{K}_{3} \mathrm{Fe}(\mathrm{CN})_{6}$ at $\mathrm{pH} 8.5$ and final purification was achieved by HPLC using the conditions described above. Purity of all peptides was greater than $97 \%$ as measured on analytical HPLC monitored at both $280 \mathrm{~nm}$ and $230 \mathrm{~nm}$. Each peptide was subjected to fast-atom bombardment mass spectrometry and in each case the appropriate, expected molecular weight was observed.

Sequential stepwise synthesis of $\left[\mathrm{Aib}^{3}\right] \mathrm{DPDPE}$ was unsuccessful, apparently due to an inability to adequately deprotect the Boc-Aib-Phe-D-Pen-resin. Thus, Boc-(S-p-MeBzl)-D-Pen-Aib-OH was prepared by solution coupling of Boc-(S-p-MeBzl)-D-PenOH to Aib-OEt followed by de-esterification of the Aib ethyl ester and was coupled to Phe-D-Pen-resin in the standard fashion. The synthesis of the peptide resin was completed in the usual manner, followed by normal cleavage and work-up procedures, as described above.

\section{$N M R$ studies}

The 'H NMR spectra were recorded on General Electric GN-500 and IBM WP 270 SY spectrometers operating at $500 \mathrm{MHz}$ and $270 \mathrm{MHz}$, respectively. NMR samples contained $1-2 \mathrm{mg}$ of the peptide in $\mathrm{D}_{2} \mathrm{O}$ ("100\%" $\mathrm{D}_{2} \mathrm{O}$, Aldrich, Milwaukee, WI) or in $\mathrm{H}_{2} \mathrm{O} /$ $\mathrm{D}_{2} \mathrm{O}(9: 1, \mathrm{v} / \mathrm{v})$ with 2,2,3,3-tetradeuterio-3-(trimethylsilyl)propionic acid, sodium salt (TSP- $\left.\mathrm{d}_{4}\right)$ added as internal standard. The $\mathrm{pH}$ of the solution was adjusted to 3 (uncorrected meter reading) using $\mathrm{CD}_{3} \mathrm{COOD}$.

Assignments were made by 2-dimensional COSY experiments (10) and sequential analysis by measurements of interproton nuclear Overhauser enhancements (11) at room temperature. In all cases 2DCOSY spectra were obtained as $256 \mathrm{~W} * 1 \mathrm{~K}$ matrices which were zero filled to $2 \mathrm{~K} * 2 \mathrm{~K}$ and multiplied by an unshifted sine bell filter function in both dimensions before Fourier transformation. Experiments to obtain temperature coefficients of various amide resonances were carried out on the GE $500 \mathrm{MHz}$ spec- 
trometer. The temperature was varied between $25^{\circ}$ and $45^{\circ}$ in steps of $5^{\circ}$ and one-dimensional spectra were acquired with $8 \mathrm{~K}$ data points. For [DAT $\left.{ }^{1}\right]$ DPDPE and DPDPE- $\mathrm{NH}_{2}$ additional 2DCOSY experiments were performed at higher temperatures to determine temperature coefficients for $\mathrm{NH}$ protons overlapped by aromatic proton signals.

\section{Receptor binding assays}

The binding assays, based on the displacement by the test compounds of radiolabeled sufentanil ( $\mu$ ligand) or DPDPE ( $\delta$ ligand) in cerebral membranes from rat brain, were performed as previously described (12, 13). Briefly, the assay mixture, containing membrane suspension in $50 \mathrm{mM}$ Tris buffer (pH 7.4), $150 \mathrm{mM}$ $\mathrm{NaCl}$, the radiolabeled ligand and the test compound, was incubated to reach binding equilibrium at $25^{\circ}$ ( $40 \mathrm{~min}$ for assays using $0.5 \mathrm{nM}\left[{ }^{3} \mathrm{H}\right]$ sufentanil; $60 \mathrm{~min}$ for $\left.1.5 \mathrm{nM}\left[{ }^{3} \mathrm{H}\right] \mathrm{DPDPE}\right)$. Subsequently, the samples were rapidly filtered and the radioactivity on the filter determined with an appropriate excess of unlabeled sufentanil or DPDPE. IC S0 $_{50}$ values were obtained by linear regression from plots relating inhibition of the specific binding in probit units to the log of five different ligand concentrations (12). In every case the correlation coefficient, $r^{2}$, of the log-probit plot was higher than 0.96 .

\section{Isolated mouse vas deferens (MVD) assay}

The MVD assays were performed as previously described (14). Briefly, $1.5 \mathrm{~cm}$ vas deferens segments from male, albino ICR mice were suspended in organ baths which contained $30 \mathrm{~mL}$ of a modified Krebs' buffer $\left(118 \mathrm{mM} \mathrm{NaCl}, 4.75 \mathrm{mM} \mathrm{KCl}, 2.54 \mathrm{mM} \mathrm{CaCl}_{2}\right.$, $1.19 \mathrm{~mm} \mathrm{MgSO}_{4}, 1.19 \mathrm{mM} \mathrm{KH}_{2} \mathrm{PO}_{4}, 11 \mathrm{~mm}$ glucose, $25 \mathrm{~mm} \mathrm{NaHCO}_{3}, 0.3 \mathrm{~mm}$ pargyline $\mathrm{HCl}, 0.2 \mathrm{~mm}$ tyro- sine, $0.1 \mathrm{~mm}$ ascorbic acid, and $0.03 \mathrm{~mm}$ sodium EDTA) saturated with $95 \% \mathrm{O}_{2}-5 \% \mathrm{CO}_{2}$ and kept at $37^{\circ}$. The segments were attached to strain gauge transducers and suspended between two platinum electrodes. After a $30 \mathrm{~min}$ equilibrium period, the segments were stimulated once every $10 \mathrm{~s}$ with pairs of pulses of $2 \mathrm{~ms}$ duration, $1 \mathrm{~ms}$ apart and at supramaximal voltage. Test compounds were evaluated for their ability to inhibit the electrically stimulated smooth muscle contractions in this preparation and complete concentration-effect relationships were determined. To assess the relative selectivity of each test compound for $\delta$ versus $\mu$ receptors, one vas deferens of each pair of vasa deferentia was studied in the presence of either $100 \mathrm{~nm}$ naltrexone, a non-selective antagonist, or $100 \mathrm{nM} \mathrm{ICI}-174864$, a $\delta$ selective antagonist, while the other vas deferens of the pair served as the control. $I C_{50}$ values were determined by probit analysis and values reported are the means of 3-9 determinations.

\section{RESULTS}

Six modifications, all of which have been previously employed in linear enkephalin analogs, were chosen for incorporation into the conformationally restricted template of DPDPE. Of interest were determining whether each modification would have a similar effect on opioid activity in DPDPE as in the flexible enkephalins and whether the conformational and structural effects of each modification could be related to the activity observed. Table 1 summarizes the binding affinities at $\mu$ and $\delta$ receptors observed for the DPDPE analogs as assessed by measuring the ability of the test compounds to displace $\left[{ }^{3} \mathrm{H}\right]$ sufentanil and $\left[{ }^{3} \mathrm{H}\right]$ DPDPE, ligands selective for the $\mu$ and the $\delta$ receptors, respectively (12). Also presented in Table 1 are

TABLE 1

Opioid receptor binding profiles and MVD potencies of DPDPE analogs

\begin{tabular}{|c|c|c|c|c|}
\hline \multirow[t]{2}{*}{ Analog } & \multicolumn{2}{|c|}{$\mathrm{IC}_{50}(\mathrm{nM})$} & \multirow{2}{*}{$\frac{\mathrm{IC}_{50}(\mu)}{\mathrm{IC}_{50}(\partial)}$} & \multirow{2}{*}{$\begin{array}{l}\mathrm{IC}_{\text {so }}(\mathrm{nM}) \\
\mathrm{MVD}\end{array}$} \\
\hline & {$\left[{ }^{3} \mathrm{H}\right]$ sufentanil } & {$\left[{ }^{3} \mathrm{H}\right] \mathrm{DPDPE}$} & & \\
\hline$\left[\mathrm{DAT}^{1}\right] \mathrm{DPDPE}$ & $>10000$ & 1680 & - & $>10000$ \\
\hline$\left[\mathrm{Aib}^{3}\right] \mathrm{DPDPE}$ & 5340 & 25.3 & $21 \mathrm{I}$ & 16.2 \\
\hline [Sar ${ }^{3}$ ]DPDPE & $>10000$ & 977 & - & $>10000$ \\
\hline [D-Phe ]DPDPE & $>10000$ & 2620 & - & $>10000$ \\
\hline$\left[\mathrm{Pgl}^{4}\right] \mathrm{DPDPE}$ & $>10000$ & $\approx 5000$ & - & $>10000$ \\
\hline DPDPE.-NH ${ }_{2}$ & 382 & 3.23 & 118 & 27.5 \\
\hline DPDPE & 7720 & 6.4 & 1200 & 7.2 \\
\hline
\end{tabular}

Binding assays performed on rat brain membrane preparations at $25^{\circ}$ in $50 \mathrm{mM}$ Tris buffer, pH 7.4 , in the presence of $150 \mathrm{mM} \mathrm{Na}^{+}$. Radioligand concentrations were $1.5 \mathrm{nM}$ for $\left[{ }^{3} \mathrm{H}\right] \mathrm{DPDPE}$ and $0.5 \mathrm{nM}$ for $\left[{ }^{3} \mathrm{H}\right]$ sufentanil.

Average ranges for the $\mu$ and $\delta$ selective binding assays were $\pm 6.5 \%$ and $\pm 10 \%$, respectively.

MVD assays performed in a modified Krebs' buffer saturated with $95 \% \mathrm{O}_{2}-5 \% \mathrm{CO}_{2}$ at $37^{\circ}$. Standard errors (SEM) for the MVD assays were $< \pm 25 \%$ of the reported mean values. 
potencies of the test compounds in the electrically stimulated mouse vas deferens (MVD) assay. In this preparation the actions of agonists at $\mu, \delta$ and $\kappa$ opioid receptors can be assessed and differentiated $(14,15)$.

As shown in Table $1, N, N$-diallyltyrosine (DAT) substitution in residue 1 leads to drastic losses in binding affinity and MVD potency. This modification has been shown to lead, at times, to fairly potent antagonists $(16,17)$, although in most cases low potency antagonists result (18). No antagonist action of [DAT']DPDPE was observed in the MVD. The inability of the simple DAT for $\mathrm{Tyr}^{1}$ substitution to convert a potent, $\delta$ selective agonist into a potent $\delta$ selective antagonist is consistent with previous observations (18).

Two modifications of residue 3 were examined within the DPDPE template. Sarcosine ( $N$-methylglycine) and $\alpha$-aminoisobutyric acid substitutions for Gly $^{3}$ were incorporated into [Sar ${ }^{3}$ ]DPDPE and [Aib ${ }^{3}$ ]DPDPE, respectively. $\mathrm{Sar}^{3}$ substitution has been reported to lead to large decreases in potency in linear enkephalin analogs (19), a result that is also observed here. As can be seen from Table 1, [Sar ${ }^{3}$ ]DPDPE displays much lower $\delta$ receptor affinity than DPDPE (ca. 150 fold) and is essentially inactive in the MVD. By contrast, [Aib ${ }^{3}$ DDPDPE retains considerable $\delta$ receptor affinity ( $1 / 4$ that of DPDPE) and selectivity (1/6 that of DPDPE) and displays considerable potency in the MVD assay ( $44 \%$ that of DPDPE). Although no in vitro results have been reported, $\mathrm{Aib}^{3}$ substitution in linear enkephalins has been reported to result in retention of activity in a behavioral in vivo assay (20).

Structural and conformational features of residue 4 have often been proposed as being of major importance for opioid activity in enkephalin analogs $(4,7$, $21,22)$. In linear enkephalin analogs, substitution of $\mathrm{Phe}^{4}$ by D-Phe ${ }^{4}(22)$ or L-phenylglycine $(\mathrm{Pgl})(19)$ results in sharp losses in binding affinity and/or potency. These observations are mirrored by the low affinities and MVD potencies observed in Table 1 for the correspondingly modified DPDPE analogs. Interestingly, Hruby and coworkers (24) have reported that $N$-methylation of the Phe residue in [NMePhe ${ }^{4}$ DPDPE leads to a great loss of potency in the MVD, a result we have also observed (unpublished results). This is counter to the usual observation that $\mathrm{NMePhe}$ substitution for $\mathrm{Phe}^{4}$ in linear enkephalins has little effect on potency or receptor selectivity (25).

It is well established that substitution of the carboxy terminal carboxylic acid function in linear enkephalins with a carboxamide enhances $\mu$ receptor affinity, potency, and selectivity. We have previously observed that carboxamide for carboxylic acid substitution in enkephalin analogs related to DPDPE but which contain a carboxy terminal $\mathrm{D}$ - or L-cysteine results in lower MVD potency but somewhat higher $\delta$ binding affinity than the corresponding carboxylic acid terminal analogs (26). The results shown in Table 1 support this finding as it can be seen that DPDPE$\mathrm{NH}_{2}$ exhibits somewhat higher $\delta$ receptor binding affinity (and much higher $\mu$ receptor affinity) but lower MVD potency than DPDPE. As seen from Table 1, DPDPE- $\mathrm{NH}_{2}$ retains considerable $\delta$ receptor binding selectivity. Similar $\delta$ selectivity can be inferred from MVD results obtained in the presence of naltrexone, a non-selective antagonist, and in the presence of ICI-174864, a $\delta$ receptor selective antagonist. As previously described $(14,27)$, similar shifts in the concentration effect curve of a test compound in the presence of each of these antagonists indicates that the test compound selectively activates $\delta$ receptors in the MVD. This is indeed observed for DPDPE- $\mathrm{NH}_{2}$, for which the $\mathrm{IC}_{50}$ in the MVD is shifted 6.7-fold in the presence of $100 \mathrm{~nm}$ ICI-174864 and 5.1-fold in the presence of $100 \mathrm{~nm}$ naltrexone.

In order to assess the effects of the structural modifications on conformation in the DPDPE analogs, conformation-dependent ' $\mathrm{H}$ NMR parameters were measured in aqueous solution. Tables 2-4 summarize these results for $\left[\mathrm{DAT}^{1}\right] \mathrm{DPDPE},\left[\mathrm{Aib}^{3}\right] \mathrm{DPDPE}$, $\left[\mathrm{Pgl}^{4}\right] \mathrm{DPDPE}$, and DPDPE- $\mathrm{NH}_{2}$ and compare the results obtained for these analogs to those observed for DPDPE. Corresponding data are not presented for [Sar $\left.{ }^{3}\right]$ DPDPE or [D-Phe ${ }^{4}$ DPDPE. The former of these exists in two conformers on the NMR time scale, presumably due to cis-trans isomerism about the DPen-Sar peptide bond, a common feature in peptides containing $N$-methyl amino acids. The latter is poorly soluble in aqueous medium; however, initial experiments in DMSO indicate conformational differences compared with DPDPE under the same conditions (unpublished observations). Further studies with both of these analogs are in progress.

Table 2 presents the chemical shift assignments, determined from 2D COSY and NOESY experiments, for four analogs of DPDPE and for DPDPE itself. For the four new analogs, Pen methyl resonances are assigned to residues 2 or 5 by analogy with DPDPE, for which the assignments are unequivocal (7). As seen from this table, chemical shifts observed for DPDPE$\mathrm{NH}_{2}$ are virtually identical to those for DPDPE while those for $\left[D A T^{1}\right] D P D P E$ differ significantly $\left(>0.15 \mathrm{ppm}\right.$ ) only for the nearby $\mathrm{D}-\mathrm{Pen}^{2} \alpha$ proton and the upfield $\gamma$ (methyl) protons. Chemical shifts for $\left[\mathrm{Pgl}^{4}\right]$ DPDPE differing significantly from DPDPE are those observed for the residue 4 amide and $\alpha$ protons, which can be directly attributed to the expected shielding differences between phenyl and benzyl side chains, and for the D-Pen ${ }^{5}$ amide proton. By contrast several chemical shift differences are seen between DPDPE and $\left[\mathrm{Aib}^{3}\right]$ DPDPE, namely those for residue $3, \mathrm{Phe}^{4}$, and $\mathrm{D}-\mathrm{Pen}^{5}$ amide protons as well as Tyr ${ }^{1}, \mathrm{D}-\mathrm{Pen}^{2}$, and $\mathrm{Phe}^{4} \alpha$ protons.

Measured values of the vicinal coupling constant, $\mathbf{J}_{\mathrm{NH} \alpha \mathrm{CH}}$, which can be related to the dihedral angle, $\phi$, 
TABLE 2

'H NMR chemical shifts and vicinal coupling constants, $J_{N H_{z} C H}$, of DPDPE analogs in aqueous solutions

\begin{tabular}{|c|c|c|c|c|c|}
\hline & Tyr $^{\prime}$ & $\mathrm{D}-\operatorname{Pen}^{2}$ & $\mathrm{X}^{3}$ & $Y^{4}$ & D-Pen ${ }^{5}$ \\
\hline NH & $\begin{array}{l}\text { a. } \\
\text { b. } \\
\text { c. } \\
\text { d. } \\
\text { e. }\end{array}$ & $\begin{array}{l}8.20 \\
8.35 \\
8.18 \\
8.25 \\
8.23\end{array}$ & $\begin{array}{l}8.52 \\
8.00 \\
8.54 \\
8.63 \\
8.43\end{array}$ & $\begin{array}{l}8.47 \\
7.98 \\
8.42 \\
8.84 \\
8.49\end{array}$ & $\begin{array}{l}7.40 \\
7.88 \\
7.36 \\
7.79 \\
7.37\end{array}$ \\
\hline $\mathbf{H}_{x}$ & $\begin{array}{l}\text { a. } 4.39 \\
\text { b. } 4.71 \\
\text { c. } 4.39 \\
\text { d. } 4.37 \\
\text { e. } 4.40\end{array}$ & $\begin{array}{l}4.19 \\
4.39 \\
4.17 \\
4.26 \\
4.00\end{array}$ & $\begin{array}{l}3.54 ; 4.35 \\
- \\
3.56 ; 4.40 \\
3.65 ; 4.40 \\
3.50 ; 4.38\end{array}$ & $\begin{array}{l}4.52 \\
4.30 \\
4.52 \\
5.28 \\
4.49\end{array}$ & $\begin{array}{l}4.43 \\
4.38 \\
4.46 \\
4.55 \\
4.38\end{array}$ \\
\hline $\mathbf{H}_{\beta}$ & $\begin{array}{l}\text { a. } 3.15 ; 3.02 \\
\text { b. } 3.29 ; 2.92 \\
\text { c. } 3.19 ; 3.07 \\
\text { d. } 3.16 ; 3.04 \\
\text { e. } 3.13 ; 3.00\end{array}$ & & $1.13 ; 1.16$ & $\begin{array}{l}3.03 ; 3.15 \\
3.05 ; 3.11 \\
3.09 ; 3.14 \\
- \\
3.05 ; 3.16\end{array}$ & \\
\hline $\mathrm{H}_{i}$ & $\begin{array}{l}\text { a. } \\
\text { b. } \\
\text { c. } \\
\text { d. } \\
\text { e. }\end{array}$ & $\begin{array}{l}1.48 ; 0.84 \\
1.45 ; 0.85 \\
1.51 ; 0.84 \\
1.53 ; 0.88 \\
1.42 ; 0.61\end{array}$ & & & $\begin{array}{l}1.34 ; 1.29 \\
1.42 ; 1.39 \\
1.29 ; 1.27 \\
1.39 ; 1.37 \\
1.31 ; 1.27\end{array}$ \\
\hline $\mathrm{H}_{\mathrm{ar}}$ & $\begin{array}{l}\text { a. } 6.87 ; 7.16 \\
\text { b. } 6.82 ; 7.13 \\
\text { c. } 6.86 ; 7.16 \\
\text { d. } 6.84 ; 7.14 \\
\text { e. } 6.82 ; 7.09\end{array}$ & & & $\begin{array}{l}7.32 \\
7.26 \\
7.33 \\
7.40 ; 7.25 \\
7.31\end{array}$ & \\
\hline $\mathrm{J}_{\mathrm{NH} \times \mathrm{CH}}(\mathrm{Hz})$ & $\begin{array}{l}\text { a. } \\
\text { b. } \\
\text { c. } \\
\text { d. } \\
\text { e. }\end{array}$ & $\begin{array}{l}7.8 \\
6.9 \\
8.5 \\
7.4 \\
7.0 \\
7.0\end{array}$ & $\begin{array}{l}4.3 ; 8.4 \\
- \\
6.2 ; 6.2 \\
4.5 ; 5.0 \\
5.5 ; 6.0\end{array}$ & $\begin{array}{l}6.0 \\
8.5 \\
6.0 \\
5.0 \\
6.0\end{array}$ & $\begin{array}{l}8.6 \\
7.5 \\
9.5 \\
9.5 \\
8.5\end{array}$ \\
\hline
\end{tabular}

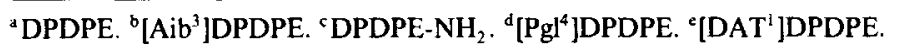

about the $\mathrm{N}-\mathrm{C}_{\alpha}$ bond (28), are also shown in Table 2. Except for differences observed for the Gly ${ }^{3}$ residue, which we have previously observed to be highly variable in the series of disulfide containing enkephalin analogs (2) and which may reflect differences in conformational averaging about this more flexible residue, the only significant $(>1.0 \mathrm{~Hz})$ differences relative to DPDPE are observed for the Phe ${ }^{4}$ and D-Pen ${ }^{5}$ residues of $\left[\mathrm{Aib}^{3}\right] \mathrm{DPDPE}$.

Temperature dependences of amide proton chemical shifts of the analogs under study are presented in Table 3. Insensitivity of the amide chemical shift to temperature $\left(\mathrm{d} \delta / \mathrm{dT}<3 \mathrm{ppb} /{ }^{\circ} \mathrm{K}\right)$ is an indication that the amide proton is inaccessible to solvent (29), which for small peptides is usually interpreted as suggesting involvement in an intramolecular hydrogen bond. As seen from Table 3, in DPDPE- $\mathrm{NH}_{2}$ and [DAT ${ }^{1}$ ]DPDPE, as in DPDPE, the D-Pen ${ }^{{ }^{2}}$ amide proton appears to be inaccessible to solvent while the other amide protons display temperature dependences consistent with exposure to the solvent. $\left[\mathrm{Pgl}{ }^{4}\right] \mathrm{DPDPE}$ is similar, although the D-Pen ${ }^{5}$ amide proton chemical shift in this analog is somewhat more sensitive to temperature, suggesting perhaps a small change in conformation of this residue relative to DPDPE. As in $\left[\mathrm{Pg}^{4}{ }^{4}\right] \mathrm{DPDPE}$, the D-Pen ${ }^{5}$ amide proton of [Aib ${ }^{3}$ ]DPDPE is somewhat more sensitive to temperature than in DPDPE. Additionally, the temperature dependence observed for the $\mathrm{Phe}^{4}$ amide proton in [Aib $\left.{ }^{3}\right]$ DPDPE is slightly less and that for the $\mathrm{X}^{3}$ residue is much less than in DPDPE. The low value of $\mathrm{d} \delta / \mathrm{dT}$ observed for the amide proton of the $\mathrm{Aib}^{3}$ residue may reflect inaccessibility due the steric influence of the $\alpha, \alpha$ dimethyl substitution.

Rotamer populations about the $\mathrm{C}_{\alpha}-\mathrm{C}_{\beta}$ bond of the $\mathrm{Tyr}^{1}$ and $\mathrm{Phe}^{4}$ side chains, calculated (30) from the vicinal coupling constants, $J_{\alpha \beta}$, are summarized in Table 4. The assignment of populations, $P$, to the specific, low energy, staggered conformations, a $\left(\chi^{\prime}=-60^{\circ}\right), \mathrm{b}\left(\chi^{\prime}=180^{\circ}\right)$, and $\mathrm{c}\left(\chi^{\prime}=60^{\circ}\right)$ is une- 
TABLE 3

Temperature dependence of amide proton chemical shifts, $d \delta / d T\left(p p b /{ }^{\circ} \mathrm{K}\right)$, for DPDPE analogs in aqueous solutions

\begin{tabular}{|c|c|c|c|c|}
\hline \multirow[t]{2}{*}{ Analog } & \multicolumn{3}{|c|}{ Residue } & \multirow[b]{2}{*}{ D-Pen ${ }^{5}$} \\
\hline & D-Pen ${ }^{2}$ & $\mathbf{X}^{3}$ & $\mathrm{Y}^{4}$ & \\
\hline DPDPE & 6.6 & 5.2 & 5.1 & 0.8 \\
\hline$\left[\mathrm{Aib}^{3}\right] \mathrm{DPDPE}$ & 8.0 & 3.1 & 4.4 & 2.6 \\
\hline DPDPE-NH & 7.1 & 5.9 & 5.0 & 0 \\
\hline$\left[\mathrm{Pg}^{4}\right]$ DPDPE & 7.0 & 5.0 & 6.4 & 2.9 \\
\hline [DAT $\left.{ }^{\prime}\right] \mathrm{DPDPE}$ & 6.1 & 5.9 & 7.8 & 0.5 \\
\hline
\end{tabular}

TABLE 4

Rotamer populations of aromatic side chains for DPDPE analogs in aqueous solutions

\begin{tabular}{|c|c|c|}
\hline \multirow[t]{2}{*}{ Analog } & \multicolumn{2}{|c|}{ Residue } \\
\hline & Tyr $^{1}$ & $\mathrm{Phe}^{4}$ \\
\hline \multirow[t]{3}{*}{ DPDPE } & $P_{a}=0.35$ & 0.58 \\
\hline & $P_{b}=0.62$ & 0.31 \\
\hline & $P_{c}=0.03$ & 0.11 \\
\hline \multirow[t]{3}{*}{ [Ajb $\mathrm{AjDPDPE}^{3}$} & $P_{a}=0.21$ & 0.58 \\
\hline & $\mathbf{P}_{\mathrm{b}}=0.72$ & 0.40 \\
\hline & $P_{c}=0.07$ & 0.02 \\
\hline \multirow[t]{3}{*}{ DPDPE-NH } & $P_{a}=0.35$ & 0.54 \\
\hline & $P_{b}=0.63$ & 0.31 \\
\hline & $P_{c}=0.02$ & 0.15 \\
\hline \multirow[t]{3}{*}[\mathrm{Pg}]{$\left.^{4}\right] \mathrm{DPDPE}$} & $P_{a}=0.35$ & - \\
\hline & $P_{b}=0.58$ & - \\
\hline & $P_{c}=0.07$ & - \\
\hline \multirow[t]{3}{*}[\mathrm{DAT}^{\prime}]{$\mathrm{DPDPE}$} & $\mathbf{P}_{\mathrm{a}}=0.35$ & 0.54 \\
\hline & $P_{b}=0.63$ & 0.31 \\
\hline & $P_{c}=0.02$ & 0.15 \\
\hline
\end{tabular}

Populations of the staggered rotamers, a $\left(\chi^{1}=-60^{\circ}\right)$, b $\left(\chi^{\prime}=180^{\circ}\right)$ and $\mathrm{c}\left(\chi^{\prime}=60^{\circ}\right)$ as calculated from $\mathrm{J}_{\alpha \beta}(30)$.

quivocal for DPDPE in which stereospecific assignment of the $\beta$ protons has been made (7). For the remaining analogs the values indicated for $\mathrm{P}_{\mathrm{a}}$ and $\mathrm{P}_{\mathrm{b}}$ may be reversed, however for analogs which appear conformationally similar to DPDPE and which display similar values of $J_{\alpha \beta}$, this is unlikely. As seen in Table 4, rotamer populations for $\mathrm{Phe}^{4}$ are virtually invariant throughout the series, although no information is available for $\left[\mathrm{Pgl}^{4}\right] \mathrm{DPDPE}$, of course. For the $\mathrm{Tyr}^{1}$ residue similar values are found throughout the series, with the exception of $\left[\mathrm{Aib}^{3}\right] \mathrm{DPDPE}$, which displays a somewhat greater preference for a single rotamer, either rotamer a, if assignments are the same as in DPDPE, or rotamer $b$, if the opposite assignment of the $\operatorname{Tyr} \beta$ protons is appropriate.

Taken together, the NMR data of Tables 2-4 suggest that the conformations, in aqueous solution, of [DAT ${ }^{1}$ DPDPE and DPDPE-NH $\mathrm{H}_{2}$ are very similar to that of DPDPE, while that of $\left[\mathrm{Pg}^{4}\right]$ DPDPE prob- ably differs, at least slightly, in the carboxy terminal region. By contrast, the presence of multiple differences in the NMR parameters of [Aib ${ }^{3}$ ]DPDPE and DPDPE, which are observed throughout the linear sequences of these analogs, suggests significant conformational differences between these peptides.

\section{DISCUSSION}

Pharmacological results for the six new analogs related to DPDPE are consistent with the previously reported effects of these modifications in flexible, linear enkephalins. Thus, $\mathrm{Sar}^{3}, \mathrm{D}-\mathrm{Phe}^{4}$, and $\mathrm{Pgl}^{4}$ substitutions all lead to drastic losses of binding affinity and MVD potency, as has been observed in linear analogs $(19,23,24)$. Substitution of $\mathrm{Tyr}^{1}$ by DAT, a substitution for which results are generally unpredictable (18), here leads to a very low potency, low affinity agonist. By contrast, the $\mathrm{Aib}^{3}$ modification, which has previously been reported to lead to active linear analogs $(20)$, results in retention of considerable $\delta$ receptor affinity, selectivity, and potency although some reduction relative to DPDPE is observed. Modification of the carboxy terminal functional group from a carboxylic acid to a carboxamide leads to the expected reduction in $\delta$ receptor selectivity due to enhanced $\mu$ receptor affinity (25). The observation that DPDPE- $\mathrm{NH}_{2}$ actually exhibits slightly higher $\delta$ receptor binding affinity than does DPDPE, which is consistent with our previous findings for other members of the cyclic, penicillamine containing enkephalin series (26), coupled with the similar conformations indicated for these analogs by the NMR data, suggests that, at least in this series, the nature of the $C$-terminal group has little influence on $\delta$ receptor recognition. The observed enhanced $\mu$ receptor affinity of DPDPE$\mathrm{NH}_{2}$ relative to DPDPE is in accord with the membrane compartment model of Schwyzer (31), which hypothesizes that the $\mu$ receptor is located in an anionic region of the cell membrane, while the $\delta$ receptor is in an uncharged or cationic area of the membrane surface. If this were the case, the observed increased $\mu$ affinity would be expected for the positively charged DPDPE- $\mathrm{NH}_{2}$ compared with the zwitterionic DPDPE due to concentration of the former by the 
negatively charged milieu of the $\mu$ receptor. However, the enhanced $\delta$ receptor affinity of the positively charged DPDPE- $\mathrm{NH}_{2}$ relative to the zwitterionic DPDPE appears to be in conflict with this model.

The apparent overall conformational similarity between [DAT ${ }^{\mathrm{l}}$ DPDPE and DPDPE leads to the conclusion that the low affinity displayed by the former can be attributed to a local effect of the diallyl substitution, although the relative importance of steric, electronic, and/or local conformational features cannot be resolved as yet. It remains unclear why, even in linear enkephalin analogs, this modification is only occasionally consistent with high receptor affinity. Also unclear is the basis for the low binding affinity and MVD potency displayed by $\left[\mathrm{Pgl}^{4}\right] \mathrm{DPDPE}$. While the NMR data suggest a local conformational difference in the backbone of this analog vs. that of DPDPE, it is uncertain whether this is a major factor in the reduced activity of this analog. In view of the considerable evidence suggesting that a specific orientation of the residue 4 aromatic side chain is a requirement for opioid activity $(4,7,21,22)$, the fixed orientation imposed upon the aromatic ring in the $\mathrm{Pgl}$ residue by its direct attachment to the peptide backbone may be of greater importance.

The observation that $\left[\mathrm{Aib}^{3}\right] \mathrm{DPDPE}$ displays similar $\delta$ receptor affinity, potency, and selectivity as DPDPE while apparently assuming a quite different conformation is particularly significant. Although several research groups employing experimental and/or computational techniques have proposed active conformations for DPDPE (3-8) there is no consensus among these reports and insufficient agreement to identify a most likely conformer. More insight into the active conformation of DPDPE, and by extension the $\delta$ receptor pharmacophore, can be gained by conformational analysis of structurally related analogs of DPDPE with both similar and different pharmacological properties. Among those analogs with similar pharmacological features, those, like $\left[\mathrm{Aib}^{3}\right] \mathrm{DPDPE}$, with apparent conformational differences compared with DPDPE are particularly valuable since within the reduced set of conformational similarities shared with DPDPE must lie those specific features required for $\delta$ receptor recognition.

[Aib ${ }^{3}$ ]DPDPE provides an additional advantage for conformational analysis since the $\alpha, \alpha$ gem dimethyl substituents of the Aib residue can be expected to further conformationally restrict this analog. In fact, allowed $\phi$ and $\psi$ values for the Aib residue are quite limited with the major region of conformational space allowed being that associated with helical and $\beta$ turn conformations (32). Such a $\beta$ turn conformation centered about $\mathrm{Aib}^{3}-\mathrm{Phe}^{4}$ has been proposed for the linear enkephalin analog Tyr-Gly-Aib-Phe- $\mathrm{MeNH}_{2}$ (20) and is consistent with the observed coupling constant, $\mathrm{J}_{\mathrm{NHaCH}}(8.5 \mathrm{~Hz})$ for the $\mathrm{Phe}^{4}$ residue of
[Aib ${ }^{3}$ DPDPE. This value for $\mathbf{J}_{\mathrm{NH} \alpha \mathrm{CH}}$, which differs considerably from that observed in DPDPE, is consistent with either a type I or type III' $\beta$ turn involving residues 2-5 (33).

By contrast the conformational differences suggested by the variation in $\mathrm{J}_{\mathrm{NH} \alpha \mathrm{CH}}$ values observed for the $\mathrm{Gly}^{3}$ residue of analogs reported here and related penicillamine containing cyclic analogs we have previously described (2) may reflect local flexibility about this residue. This residual flexibility in DPDPE may also underlie the lack of consensus among the models proposed for the conformation of this peptide, as has been previously suggested (7). More detailed conformational analyses of [Aib ${ }^{3}$ ]DPDPE as well as other analogs of DPDPE, which are in progress, should allow the proposal of a reasonable, consistent model for the required conformation for $\delta$ opioid receptor binding.

\section{ACKNOWLEDGMENTS}

This work was supported by USPHS grants DA 03910 (H.I.M.) and DA 00254 (H.I.M., F.M., C.B.S.). The General Electric GN500 NMR spectrometer was purchased in part by funds from USPHS grant RR 02415 and by funds from the University of Michigan, College of Pharmacy.

\section{REFERENCES}

1. Mosberg, H.I., Hurst, R., Hruby, V.J., Gee, K., Yamamura, H.I., Galligan, J.J. \& Burks, T.F. (1983) Proc. Natl. Acad. Sci. USA 80, 5871-5874

2. Mosberg, H.I. (1987) Int. J. Peptide Protein Res. 29, 282-288

3. Keys, C., Payne, P., Amsterdam, P., Toll, L. \& Loew, G. (1988) Mol. Pharmacol. 33, 528-536

4. Hruby, V.J., Kao, L.F., Pettitt, B.M. \& Karplus, M. (1988) J. Am. Chem. Soc. 110, 3351-3359

5. Nikiforovich, G.V.\& Balodis, J. (1988) FEBS Lett. 227, 127130

6. Froimowitz, M. \& Hruby, V.J. (1989) Int. J. Peptide Protein Res. 34, 88-96

7. Mosberg, H.I., Sobczyk-Kojiro, K., Subramanian, P., Crippen, G.M., Ramalingam, K. \& Woodard, R.W. (1990) J. Am. Chem. Soc. 112, 822-829

8. Wilkes, B.C. \& Schiller, P.W. (1990) in Proceedings of the 11th American Peptide Symposium, (Rivier, J. \& Marshall, G.R., eds.), pp. 34I-343

9. Mosberg, H.I., Haaseth, R.C., Ramalingam, K., Mansour, A., Akil, H. \& Woodard, R.W. (1988) Int. J. Peptide Protein Res. $32,1-8$

10. Aue, W.P., Bartholdi, E. \& Ernst, R.R. (1976) J. Chem. Phys. 64, 2229-2246

11. Bodenhausen, G., Kogler, H. \& Ernst, R.R. (1984) J. Magn. Resonance 58, 370-388

12. Clark, M.J., Carter, B.D. \& Medzihradsky, F. (1988) European J. Pharmacol. 148, 343-351

13. Fischel, S.V. \& Medzihradsky, F. (198I) Mol. Pharmacol. 20, 269-279

14. Smith, C.B. (1987) in NIDA Research Monograph Series No. 76: Problems of Drug Dependence 1986, pp. 288-294 
R.C. Haaseth et al.

15. Smith, C.B., Bennett-Kelly, L. \& Woods, J.H. (1984) Neuropeptides 5, 16I-164

16. Shaw, J.S., Miller, L., Turnbull, M.J., Gormley, J.J. \& Morley, J.S. (1982) Life Sci. 31, 1259-1262

17. Cotton, R., Giles, M.G., Miller, L., S•aw, J.S. \& Timms, D. (1984) European J. Pharmacol. 97, 331-332

18. Thornber, C.W., Shaw, J.S., Miller, L., Hayward, C.F., Morley, J.S., Timms, D. \& Wilkinson, A. (1987) in NIDA Research Monograph Series No. 75: Progress in Opioid Research, pp. 177-180

19. Beddell, C.R., Clark, R.B., Hardy, G.W., Lowe, L.A. Ubatuba, F.D., Vane, J.R., Wilkinson, S., Chang, K.-J., Cuatrecasas, P. \& Miller, R.J. (1977) Proc. R. Soc. London, Ser. B. 198, 249-265

20. Sudha, T.S. \& Balaram, P. (1983) Int. J. Peptide Protein Res. 21, 381-388

21. Shimohigashi, Y., Costa, T., Nitz, T.J., Chen, H.C. \& Stammer, C.H. (1984) Biochem. Biophys. Res. Commun. 121, 966-972

22. Fournie-Zaluski, M.-C., Gacel, G., Maigret, B., Premilat, S. \& Roques, B.P. (1981) Mol. Pharmacol. 20, 484-491

23. Morley, J.S. (1980) Ann. Rev. Pharmacol. Toxicol. 20, 81-110

24. Hruby, V.J., Kao, L.-F., Hirning, L.D. \& Burks, T.F. (1985) in Peptides: Structure and Function. Proceedings of the Ninth American Peptide Symposium (Deber, C.M., Hruby, V.J. \& Kopple, K.D., eds.), pp. 487-490

25. Hansen, P.E. \& Morgan, B.A. (1984) in The Peptides: Analy- sis, Synthesis, Biology, (Udenfriend, S. \& Meienhofer, J., eds.), Vol. 6, pp. 269-321

26. Mosberg, H.I., Hurst, R., Hruby, V.J., Galligan, J.J., Burks, T.F., Gee, K. \& Yamamura, H.I. (1983) Life Sci. 32, 25652569

27. Mosberg, H.I., Omnaas, J.R., Medzihradsky, F. \& Smith, C.B. (1988) Life. Sci. 43, 1013-1020

28. Bystrov, V.F. (1976) Progress in Nuclear Magnetic Resonance Spectroscopy 10 (part 2), 41-81

29. Deslauriers, R. \& Smith, I.C.P. (1980) in Biological Magnetic Resonance (Berliner, L.J. \& Reuben, J., eds.), Vol. 2, pp. 243-344

30. Pachler, K.G.R. (1964) Spectrochim. Acta 20, 581-587

31. Schwyzer, R. (1986) Biochemistry 25, 6335-6342

32. Marshall, G.R. \& Bosshard, H.E. (1972) Circulation Res. 30/31 (Suppl. II), 143-150

33. Kishore, R. \& Balaram, P. (1986) in NIDA Research Monograph Series No. 69; Opioid Peptides: Medicinal Chemistry, pp. 312-331

Address:

Dr. Henry I. Mosberg

College of Pharmacy

University of Michigan

Ann Arbor, MI 48109-1065

USA 